\title{
SINERGIA
}

REVISTA DO INSTITUTO DE CIÊNCIAS ECONÔMICAS, ADMINISTRATIVAS E CONTÁBEIS (ICEAC)

\section{O EFEITO DA EDUCAÇÃO FINANCEIRA SOBRE A RELAÇÃO ENTRE ADIMPLÊNCIA E TRABALHADORES NA CIDADE DE MANAUS}

\author{
DIOGO DEL FIORI \\ ROSANA ZAU MAFRA \\ TATIANE AMENDOLA FERNANDES* \\ JOSÉ BARBOSA FILHO \\ LUIZ ROBERTO COELHO NASCIMENTO**
}

\begin{abstract}
RESUMO
O objetivo da pesquisa foi analisar o efeito da educação financeira sobre a inadimplência dos trabalhadores em Manaus. A educação financeira é importante para toda a população, pois, por meio dela, disseminam-se os conhecimentos e informações acerca deste assunto, contribuindo para uma significativa melhora na administração das finanças pessoais dos cidadãos. Por isso, é importante a criação de um planejamento orçamentário pessoal para controlar os gastos, evitando, assim, um futuro endividamento. Foi realizada uma pesquisa de natureza qualiquantitativa e descritiva, caracterizada como uma pesquisa de campo. Com relação aos resultados, nota-se que o nível de endividamento da maior parte dos trabalhadores entrevistados na cidade de Manaus é baixo, embora ocorra o uso intenso do cartão de crédito e também o pagamento das faturas em atraso. Com relação à educação financeira, muitos consideram não possuir muito conhecimento sobre seus gastos e finanças, o que os fazem procurar informações sobre o assunto, apesar de declararem a dificuldade em aplicar os conhecimentos diariamente. Com relação àqueles que declaram ter um conhecimento maior sobre suas finanças, a probabilidade de se endividarem é menor, embora exista a possibilidade de contraírem dívidas e se tornarem inadimplentes.
\end{abstract}

Palavras-chave: Educação Financeira, Inadimplência, Finanças Pessoais, Controle Financeiro.

\section{ABSTRACT}

The objective of the research was to analyze the effect of financial education on the delinquency of workers in Manaus. Financial education is important for the entire population, since it disseminates knowledge and information about this subject, contributing to a significant improvement in the administration of personal finances of citizens. Therefore, it is important to create a personal budget planning to control expenditures, thus avoiding future indebtedness. A qualitativequantitative and descriptive research was conducted, characterized as a field research. Regarding the results, it is noted that the level of indebtedness of the majority of the workers interviewed in the city of Manaus is low, although the heavy use of the credit card occurs and also the payment of the arrears. With regard to financial education, many consider that they do not have much knowledge about their spending and finances, which makes them look for information on the subject, although they declare the difficulty in applying the knowledge daily. With respect to those who claim to have greater knowledge about their finances, the likelihood of borrowing is lower, although there is the possibility of incurring debt and becoming defaulted.

Keywords: Financial Education, Default, Personal Finance, Financial Control.

Recebido em: 27-08-2017 Aceito em: 20-02-2018

\section{INTRODUÇÃO}

O mercado financeiro está sempre em atualização e a facilidade para compra de alguns produtos atrelados ao grande marketing das empresas faz com que as pessoas que têm pouco conhecimento financeiro se prejudiquem. Com a falta de informação sobre esse assunto, fica mais difícil lidar com a administração financeira pessoal, o que pode acarretar um endividamento. A partir daí, entra em vigor o tema Educação Financeira, como um meio para garantir uma melhor administração das finanças pessoais (TOLOTTI, 2007).

A partir de 1999, o cenário econômico brasileiro passou por algumas transformações e melhorias, e

\footnotetext{
"Professor Adjunto do departamento de economia e análise da FES (Faculdade de Estudos Sociais)

"Departamento de economia e análise da FES (Faculdade de Estudos Sociais)

*.* Departamento de economia e análise da FES (Faculdade de Estudos Sociais)

...... Departamento de economia e análise da FES (Faculdade de Estudos Sociais)

Professor Adjunto do departamento de economia e análise da FES (Faculdade de Estudos Sociais)
} 
alguns determinantes, como o controle da inflação e a expansão dos bancos, contribuíram para melhorar o conceito de educação financeira. No entanto, na prática, não havia qualquer expressão de melhoria e nenhuma ação ou projeto tinha sido criado para aqueles cidadãos que não tinham acesso ao assunto. Foi só em 2010, por meio do Decreto 7397/2010, que o Governo Federal criou a Estratégia Nacional de Educação Financeira (ENEF), iniciando o processo de disseminação da Educação Financeira.

Endividamento pode ser de cunho familiar e individual, sendo que, para alguns, o ato de ficar endividado consiste em deixar de pagar uma única conta, por exemplo; já para outros, se possuem um grande acúmulo durante vários meses de contas não pagas. O mais importante é que cada um saiba lidar com o dinheiro e que esteja consciente de todas as obrigações que terão que ser pagas ao realizar uma compra ou aquisição de um serviço a prazo. Dessa forma, o presente estudo, por intermédio da educação financeira, tem como objetivo verificar a relação entre controle financeiro pessoal e 0 grau de endividamento dos trabalhadores na cidade de Manaus.

São inúmeras as causas que podem ser listadas para o endividamento de acordo com o Serasa Experian (2016), sendo que o desemprego é a principal causa, o que pode ser explicado pela atual situação econômica do país, em que muitas empresas estão demitindo funcionários e aquelas pessoas que tinham adquiridos dívidas para serem pagas a longo prazo, como a compra de um carro, foram prejudicadas e estão com dificuldades de pagar, o que ocasiona maiores chances de endividamento. A segunda causa da inadimplência é o descontrole financeiro, que está relacionado com a falta de planejamento, pois a renda gasta por algumas pessoas na compra de produtos ou serviços para serem pagos a longo prazo está acima do orçamento, o que ocasiona problemas no momento de realizar os devidos pagamentos.

Nota-se que, nos últimos anos, há um maior interesse no que tange aos estudos do comportamento dos indivíduos quanto às decisões financeiras. Inúmeras correntes atreladas à ciência - como a Teoria dos Jogos, Finanças comportamentais, Marketing e a psicologia econômica - estão dedicadas à análise do comportamento dos consumidores no que se refere ao comportamento de se endividar, poupar, consumir, vender e comprar. Perante o elevado nível de consumo, inúmeros indivíduos adquirem dívidas, tornando comprometida uma intensa fração da sua renda, transformando-se em inadimplentes em muitos casos. Levando-se em consideração a existência de inúmeros produtos, tais como fundos de investimento, poupança, crédito direto ao consumidor, financiamentos, cartão de crédito, cheque especial etc., há a necessidade de os indivíduos estarem preparados para administrar contextos cada vez mais complexos ao terem por meta comprar um serviço ou bem (BORGES et al, 2010). A Educação Financeira se faz presente para auxiliar o indivíduo a melhorar a gestão do uso da sua renda e também a criar um melhor planejamento orçamentário doméstico e, dessa forma, estabelecer uma vida financeira saudável. Estudos acerca da educação financeira estão ganhando cada vez mais espaço no Brasil, e, por meio desta pesquisa, será possível relacionar a inadimplência com o efeito que a educação financeira tem na vida dos indivíduos e famílias, ou seja, espera-se compreender como a educação financeira e suas ferramentas podem servir como estratégia para impedir um maior endividamento pelos cidadãos. De acordo com Borges et al. (2010), a Educação Financeira possui grande importância, haja vista que os indivíduos têm suas vidas impactadas, no decorrer do tempo, pelas decisões tomadas. Dessa forma, ao escolherem o investimento, as pessoas fazem escolhas de cunho financeiro. Também fazem escolhas ao escolherem não fazerem poupança para consumirem no presente. Outra escolha se refere à antecipação do consumo futuro por intermédio da aquisição de financiamentos.

\section{REVISÃO DA LITERATURA}

\subsection{Pesquisas Recente}

Piccini e Pinzetta (2014) realizaram um estudo por meio do levantamento de dados quantitativos por intermédio de questionários para tentar buscar uma compreensão sobre as finanças pessoais, o índice de endividamento e o índice de conhecimento financeiro da população do Município de Chapecó. Os resultados mostram que Chapecó detém um patamar de endividamento e de conhecimento positivos, diferentemente da população do Brasil e do Estado de Santa Catarina. É elevado o nível de instrução da população de Chapecó quando se compara a outros estados e ao Brasil, tendo um patamar acima de $70 \%$ com ensino superior, cursando e completo. Isso faz com que o índice de conhecimento fique acima do nível nacional. Com relação à amostra total composta pelos respondentes, $67 \%$ possuem mais de $30 \%$ da renda comprometida com obrigações mensais e empréstimos. Os respondentes em geral disseram conhecer temas que englobam orçamento doméstico e planejamento, mas se nota que somente $5 \%$ da totalidade têm informação para realizar investimento.

Araujo e Calife (2014) estudaram o comportamento do consumidor com relação ao crédito em 2014 no 
Brasil. De acordo com os resultados, houve um amadurecimento dos consumidores, haja vista as maiores oportunidades de controle e planejamento, bem como a elevação de medidas visando à educação financeira pelos indivíduos do mercado e também a um acesso maior à informação. Com relação ao total de respondentes, $75 \%$ disseram que realizam o controle do montante recebido e que despendem mensalmente, sendo que $34 \%$ disseram conseguir guardar recursos depois de pagarem as contas, sendo que a poupança $(70 \%)$ é o principal destino desse montante economizado. No que tange à decisão para aquisição, 93\% disseram possuir um preparo mais elevado se comparado com a situação na qual se encontravam há 4 anos. Observou-se que os consumidores estão mais maduros, tendo em vista que $80 \%$ dos respondentes disseram possuir informações de como administrar o dinheiro. O estudo também mostrou que $65 \%$ dos consumidores possuem preferências em fazer o dispêndio das compras em parcela única ou à vista $(5 \%$ com cheque e boleto, $26 \%$ com dinheiro, $29 \%$ com cartão de crédito e $40 \%$ no cartão de débito). Dos 35\% que realizam compras em prestações, neste caso, $4 \%$ usam cartão de débito, $20 \%$ preferem carnê/boleto e cheque pré-datado, e $76 \%$ fazem parcelamento de pagamento por meio do uso do cartão de crédito.

O estudo de Santos e Silva (2014) teve por meta identificar as causas primordiais para o endividamento financeiro familiar na Bahia e no Sergipe. Com relação às características dos entrevistados, notou-se uma igual distribuição entre mulheres $(46,15 \%)$ e homens $(53,85 \%)$, sendo que os indivíduos predominantes estão em uniões estáveis ou são casados [Bahia (47,69\%) e Sergipe (48,46\%)]. Com relação à idade, o percentual mais elevado, nos dois estados, foi o das idades de 24 e 29 anos, seguido de 18 e 23 anos. As outras faixas etárias tiveram percentuais muito baixos. Em Sergipe, grande parte dos respondentes afirmaram já terem ouvido a respeito de controle pessoal, entretanto, 40,77\% nunca tiveram conhecimento e nao sabiam do que se tratava o tema educação financeira. Na Bahia, a percentagem daqueles que nunca tiveram conhecimento a respeito de educação financeira foi $15,39 \%$ maior com relação aos indivíduos que tiveram conhecimento sobre este assunto. Também na Bahia, foi constatada uma concentração elevada de renda no intervalo entre 0,00 e 2,034,00 (76,15\%). Um número expressivo de famílias possuem uma renda líquida entre 2.035,00 e 4.069,00 (26,15\%), e mais da metade das familias possui uma renda entre 676,00 e $2034,00(58,46 \%)$ na região metropolitana de Sergipe. Na Bahia, 33,85\% dos respondentes apresentam comprometimento na renda mensal de 41 a $60 \%$ dos ingressos líquidos mensais, sendo que 26,92\% têm comprometimento da renda de 61 a $80 \% ; 13,08 \%$ possuem um comprometimento dos seus ganhos mensais maior do que $80 \%$. Do total da renda comprometida, $22,33 \%$ equivale à moradia; $17,67 \%$, a aquisições com cartão de crédito; $32,67 \%$, à alimentação. Em Sergipe, $25,08 \%$ dos ganhos mensais é despendido com cartão de crédito e $30,36 \%$, com alimentação e $34,62 \%$ dos respondentes disseram estar endividados. Com relação a maneira pela qual os entrevistados costumam pagar suas dívidas, na Bahia, 22,31\% pagam em atraso e 56,15\% cumprem seus compromissos no período estipulado. Ainda em Sergipe, 14,62\% pagam em atraso e 73,08\% dos respondentes pagam as contas em dia.

\subsection{Inadimplência}

De acordo com Houaiss (2004, p. 406), a palavra inadimplência significa "o não cumprimento de uma obrigação". É considerado inadimplente o indivíduo que faz uma compra para ser pagar em algum momento, diferente do endividado, que é apenas aquela pessoa que comprou algo antes da data do pagamento. Para Teixeira (2001, p. 19), "inadimplência é a falta de pagamento; inadimplemento é o termo jurídico utilizado em regra, para designar uma situação de não cumprimento da cláusula contratual".

Segundo Katona (1975, apud MALMANN et al., 2009), é comum ver pessoas gastando mais do que ganham em diversas camadas sociais, e isso é uma das causas do endividamento e da inadimplência. Alguns indivíduos querem usufruir além do seu poder de compra e acabam gastando mais do que ganham; outros possuem uma renda alta, mas não estão satisfeitos com o que possuem, fazendo-os consumir sempre mais. Outra razão é pela escolha em não economizar, independente de estar na classe baixa ou alta, dado a falta de vontade em poupar e controlar suas finanças (KATONA 1975 apud MALMANN et. al., 2009). Ainda de acordo com o Boa Vista SCPC (2016), regionalmente, de abril de 2016 contra abril de 2015, o Norte apresentou a maior elevação, de 4,0\%, seguido pelo Sudeste, onde o indicador subiu 1,0\%."

TABELA 1 - Registro de inadimplência no acumulado de 12 meses de abril de 2015 a abril de 2016 por regiões do Brasil.

\begin{tabular}{ccccc}
\hline & Acum 16/15 & abr-16/abr-15 & abr-16/mar-16* & 12 meses \\
\hline Centro Oeste & $6,7 \%$ & $-0,5 \%$ & $1,0 \%$ & $6,4 \%$ \\
Norte & $6,0 \%$ & $4,0 \%$ & $7,9 \%$ & $3,9 \%$ \\
Nordeste & $5,0 \%$ & $-0,5 \%$ & $3,5 \%$ & $2,8 \%$ \\
Sul & $-1,8 \%$ & $-5,5 \%$ & $3,9 \%$ & $4,4 \%$ \\
Sudeste & $4,9 \%$ & $1,0 \%$ & $-3,0 \%$ & $2,9 \%$ \\
Brasil - Geral & $\mathbf{4 , 3} \%$ & $-\mathbf{0 , 1} \%$ & $\mathbf{- 0 , 2} \%$ & $\mathbf{3 , 5 \%}$ \\
\hline
\end{tabular}

*Séries Dessazonalizadas

FONTE: Boa Vista SCPC (2016) 
O consumismo varia muito entre os indivíduos, alguns conseguem manter um equilíbrio entre um produto ou serviço que pode ser ou não adquirido dentro do orçamento atual, já outros consomem muito além do que realmente precisam e se a compra for realizada com um cartão de crédito, a maior parte se atrapalha ao realizar os pagamentos seguintes. De acordo com Tolotti $(2010$, p. 1), "O endividado é aquela pessoa que se joga para um risco. Ela não sabe como vai pagar, mas mesmo assim compra". Existem algumas maneiras de classificar os endividados, entre elas, o ativo, que é considerada aquela pessoa que não se controla ao realizar uma compra, independente da situação financeira, e independente, também, se está precisando ou não. A segunda categoria é o sobre-endividado, aquele que sabe que está com dívidas, mas se vir alguma chance de comprar, procura meios para realizá-la. Já o passivo é considerado aquele que está endividado por alguma eventualidade, e precisou buscar ajuda financeira em bancos comerciais ou com outras pessoas (TOLOTTI, 2010).

O consumo de forma descontrolada pode levar ao endividamento, mas existem alguns fatores que conduzem ao consumismo além do necessário. Algumas das razões estão ligadas à forma como a família lida com o dinheiro e a maneira como essas atitudes são passadas aos filhos no decorrer da vida. Existe também uma preocupação do indivíduo em mostrar para a sociedade que possui algum produto que está na moda ou que usufrui de algum serviço que somente pessoas com alta renda podem utilizar. Portanto, observa-se que a inadimplência é um fenômeno isolado e que não depende de nível social, gênero etc. e que, por isso, vem sendo objeto de preocupação de governos mundiais (FERREIRA, 2007).

\subsection{Educação Financeira} como:

A Organização de cooperação e Desenvolvimento Econômico (OCDE) define a educação financeira

[...] o processo em que os consumidores e investidores melhoram a sua compreensão dos produtos financeiros, conceitos e riscos e, por meio de informação, instrução e orientação objetiva, desenvolvem habilidades e ganham confiança para se tornarem mais conscientes dos riscos financeiros, fazendo escolhas bem informadas e sabendo onde ir para obter ajuda, além de tomar outras ações efetivas para melhorar o seu bem-estar financeiro (OCDE, 2009, p. 1).

Sendo assim, o governo nacional teve por objetivo oferecer à população uma educação boa o suficiente para que todos tenham condições de lidar e administrar os recursos financeiros pessoais e entender como funciona o mercado por meio do estudo da influência dos juros na vida de cada um e também da busca do entendimento de como se comportar diante das oportunidades de créditos oferecidas, bem como ajudar a decidir entre adquirir ou não algum produto parcelado em alguma loja. Segundo Gallery et al. (2011, p. 288), educação financeira é "a capacidade de fazer julgamentos inteligentes e decisões eficazes em relação ao uso e gestão do dinheiro". Uma educação de qualidade pode ter efeitos positivos na vida pessoal e profissional de cada indivíduo. A educação pode ter uma atribuição específica para cada área, como, por exemplo, na área financeira, que oferece auxílio para as pessoas entenderem sobre o uso da matemática no dia a dia e como tudo aquilo estudado na escola pode ser aplicado na prática em benefício próprio (MALCOLM 2000 et. al apud SANTANA2014).

São diversos os alcances que a educação financeira proporciona, como um planejamento orçamentário que possibilita ao indivíduo acompanhar todas as receitas e despesas que está tendo no momento com o fito de educá-lo para que consiga poupar recursos financeiros para realizar investimentos futuros. Cabral $(2013$, p. 3) afirma que, "na realidade, não é quanto dinheiro se ganha que faz a diferença, mas quanto dinheiro se guarda ou, ainda, quanto o dinheiro trabalha aumentando-o, e por quantas gerações ele se manterá".

Para que um indivíduo na vida adulta possa ter maior facilidade em lidar com problemas de finanças pessoais e planejamento do orçamento, é necessário que, na fase anterior, tenha tido uma base sobre esses assuntos para que consiga adquirir conhecimentos e aplicá-los durante a vida. Dado que alguns adolescentes passam parte do dia na escola, a instituição escolar influencia, assim como a família, nas maneiras que os mesmos tratam os assuntos que envolvem sociedade e vida pessoal. Da mesma forma que as outras matérias presentes no histórico escolar, são ministradas na sala de aula, a matéria Educação Financeira também deveria sê-lo.

Algumas informações sobre finanças pessoais que deveriam ser de conhecimento geral da população são muitas vezes desconhecidas. Em 2008, por meio de uma pesquisa nacional, foi comprovado que $82 \%$ dos brasileiros que realizaram algum tipo de empréstimo não possuíam sabedoria sobre a taxa de juros cobrada e que os atrasos eram devido ao mau planejamento com os recursos financeiros (AEF, 2012). Diante do contexto acima, a educação financeira se torna importante para auxiliar os indivíduos a terem melhores escolhas para reduzir a taxa de inadimplência. Em diversos países, projetos educacionais são desenvolvidos por meio do governo e das instituições privadas. 


\subsection{Iniciativas nacionais de Educação Financeira}

O governo decidiu tomar algumas atitudes, entre elas, lançar um programa chamado Estratégia Nacional de Educação Financeira - ENEF, através do Decreto nํㅜ 7.397, de 22 de dezembro de 2010, o qual objetiva:

[...] desenvolver uma proposição de Estratégia Nacional de Educação Financeira, prevendo a promoção de um inventário nacional de ações e de projetos de educação financeira no país, além de uma pesquisa que mapeie o grau de conhecimento financeiro da população brasileira. Além das ações destinadas ao público-alvo para adultos, o ENEF prevê ações voltadas para as escolas, seguindo uma tendência mundial. Este organismo tem como principais objetivos promover e fomentar a cultura de educação financeira no país, ampliar a compreensão do cidadão, para que seja capaz de fazer escolha consciente quanto à administração de seus recursos e contribuir para a eficiência e solidez dos mercados financeiros, de capitais, de seguros, de previdência e de capitalização (BRASIL, 2009, p. 02).

Existem outras ações e projetos, entre eles a do Banco Central do Brasil, que possui um Programa de Educação Financeira (PEF-BC) com a meta de ser ofertado à população brasileira por intermédio da disponibilização de materiais impressos e eletrônicos, com o intuíto de conscientizar sobre a importância da administração financeira e também ensinar as operações básicas que uma pessoa deve conhecer. Para tal, são promovidos ciclos de palestras e a disponibilização na Internet do material sobre o tema (BACEN, 2013).

A partir da construção do planejamento estratégico e das prioridades da Comissão de Valores Mobiliários para os anos de 2013 a 2023, foram estabelecidos alguns objetivos estratégicos, dentre eles, o papel de liderança na área de educação financeira, contribuindo para que seja difundido, de forma simplificada, para população que queira fazer investimentos e que saiba os riscos e benefícios dos produtos financeiros disponibilizados por instituições financeiras (CVM, 2013). "A educação financeira, como conjunto de ações de informação, formação e orientação, consiste em elemento primordial para que a população possa melhorar a compreensão dos produtos e serviços financeiros" (CVM, 2013, p. 33). Dessa forma, a CVM criou alguns objetivos a serem alcançado até o ano de 2023, entre eles:

- Expandir dentro da área acadêmica o conhecimento sobre o mercado de capitais brasileiro.

- Criar uma aproximação da Comissão de Valores Mobiliários com a população, incentivando a população a procurar meios para investir.

- Utilizar os meios de comunicação para captar investidores iniciantes e poder ajudá-los a melhorar seus conhecimentos sobre investimento.

\subsection{Educação Financeira: Uma Aplicação no cenário Internacional}

O artigo elaborado por Garman et al. (1999) fez um estudo em uma das várias fábricas de propriedade de uma empresa de produção de produtos químicos do Sudeste dos Estados Unidos para investigar a eficácia do curso de educação financeira no local de trabalho oferecido pelo grupo EDSA. Dos 300 funcionários, 178 responderam. Cem entrevistados (56\%) participaram das oficinas de educação financeira, e $78(44 \%)$ não participaram de nenhuma das oficinas. A maioria dos respondentes (92\%) são homens, $75 \%$ dos respondentes são casados (76\%), enquanto $14 \%$ são solteiros. Três quartos possuem educação além do diploma do Ensino Médio. Os trabalhadores são brancos (91\%) e 87\% relataram renda doméstica de US\$ 50000 ou mais. Cerca de metade dos trabalhadores (49\%) vive em um lar de três ou quatro pessoas. A idade mediana dos trabalhadores é de 43 anos. A demografia da amostra corresponde bem com a população da empresa, conforme relatado pelo Gerente de Relações Industriais. Os participantes da oficina relataram fazer uma série de mudanças de comportamento financeiro pessoal como resultado da educação recebida. Três quartos $(75 \%)$ dos participantes da oficina informaram que eles tomaram melhores decisões financeiras desde que participaram das oficinas; setenta e cinco por cento relataram que estavam mais confiantes em tomar decisões de investimento; setenta por cento informaram que mudaram sua estratégia de investimento diversificando ou sendo mais agressivos em suas escolhas de investimento; cinquenta e seis por cento concordaram que sua situação financeira melhorara devido à educação financeira. Quase metade $(45 \%)$ dos participantes da oficina aumentou a contribuição para o plano de previdência $401(\mathrm{k})$ da empresa; trinta e quatro trabalhadores concordaram que eles começaram a contribuir para o plano 401 (k) como resultado das oficinas de educação financeira.

Mandell e Klein (2009) realizaram um estudo para examinar o impacto diferencial em 79 alunos do Ensino Médio de um curso de Gestão Financeira nos Estados Unidos. Os resultados mostram que o curso de Gestão Financeira Pessoal não impactou sistematicamente os recursos financeiros do entrevistado. Aqueles que participaram do curso eram mais propensos a fazer pagamentos com cartão de crédito a 
tempo; no entanto eles também eram menos propensos a pagar seu cartão de crédito na íntegra todos os meses. Portanto, os entrevistados que seguiram o curso eram mais propensos a pagar juros sobre o saldo do seu cartão. Além disso, enquanto uma maior proporção daqueles que cursavam o curso equilibrou seu talão de cheques; eles também tinham maior probabilidade de ter recusado um cheque. Além disso, aqueles que não tinham tomado o curso eram mais propensos a preparar seus próprios impostos e acreditam que possuem economias e investimentos adequados.

\section{METODOLOGIA}

Esta pesquisa é quali-quantitativa, descritiva e de campo. Qualitativa, porque tem o intuito de avaliar e aprofundar a compreensão da relação entre a educação financeira e os trabalhadores inadimplentes na cidade de Manaus. Quantitativa, porque adota informações numéricas por intermédio de dados pesquisados, oriundos do questionário aplicado por meio da pesquisa de campo, buscando-se analisar a relação entre educação financeira e os trabalhadores inadimplentes na cidade de Manaus, utilizando-se dados primários coletados e posteriormente tratados por meio de softwares, como o Microsoft Office Excel 2003.

Classifica-se, também, a pesquisa, como de campo, realizada por meio de coletas de informações, tendo como instrumento a aplicação de questionário. A pesquisa de campo focaliza uma comunidade, que não é necessariamente geográfica, como regiões ou nações, mas pode ser também um grupo de pessoas de trabalho, de estudo ou de lazer. A pesquisa coletará dados para estabelecer correlações entre educação financeira e adimplência dos trabalhadores de Manaus e a análise de dados pela aplicação de survey.

Foi realizada uma pesquisa de campo, sendo o instrumento aplicado um questionário semiestruturado, composto por 20 questões elaboradas pelos autores com base no trabalho de Günther (2003), com perguntas fechadas e abertas de múltipla escolha elaborada pelos autores, dividida em três partes, abrangendo cidadãos selecionados aleatoriamente da cidade de Manaus, que possuem um emprego, independente de setor ou renumeração, com faixa etária acima de 18 anos, os quais responderam ao questionário no mês de maio do ano de 2016, que obteve um total de sessenta e seis respondentes Trata-se, portanto, de uma amostra não probabilística por acessibilidade, sendo o instrumento preenchido pessoalmente ou via internet pelo Google Drive. Os dados foram tabulados por meio do Microsoft Office Excel 2003. Foram também calculados os percentuais de cada questão individualmente e feitas algumas correlações entre as variáveis relevantes para a pesquisa. Não houve um pré-teste do questionário.

\section{RESULTADOS}

A pesquisa averigua se aqueles que possuem educação financeira estão menos propensos a se endividarem ou não. A análise dos resultados está dividida em três subseções, sendo a primeira referente ao conhecimento do perfil dos respondentes, a segunda de dados da gestão das finanças pessoais, e a terceira sobre o perfil das compras, despesas e pagamentos dos entrevistados.

\subsection{Identificação do entrevistado e status profissional}

De acordo com a análise dos dados, foram obtidos os seguintes resultados: foram entrevistadas 66 pessoas de forma aleatória, sendo que $27 \%$ das delas estão na faixa etária entre 16 até 24 anos. Aqueles com idade entre 39 a 50 anos correspondem a $23 \%$, e o restante, a partir dos 51 anos, representam $20 \%$.

Do total dos entrevistados, $55 \%$ não possuem dependentes financeiros, isto é, não sustentam nenhuma outra pessoa e toda a renda salarial vai para uso próprio. Os $45 \%$ restantes sustentam outras pessoas com o salário, como, por exemplo, os filhos ou os pais. No que se refere ao nível de escolaridade dos entrevistados, $5 \%$ detêm Ensino Médio completo; 46\%, Ensino Superior incompleto; $25 \%$, Ensino Superior completo, $23 \%$ cursaram pós-graduação e apenas $1 \%$ ainda não completou o Ensino Médio. Ao questionar os entrevistados a respeito do gênero, constatou-se que, dos 66 respondentes, $58 \%$ são homens e $42 \%$, mulheres. Os dados descritos constam nas figuras a seguir. 


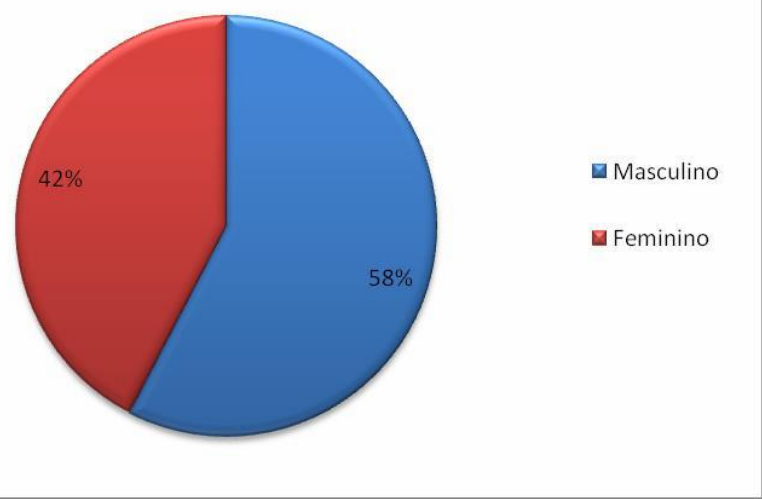

FIGURA 1 - Percentual de gênero dos trabalhadores da cidade de Manaus no período de maio de 2016. FONTE: Elaboração própria.

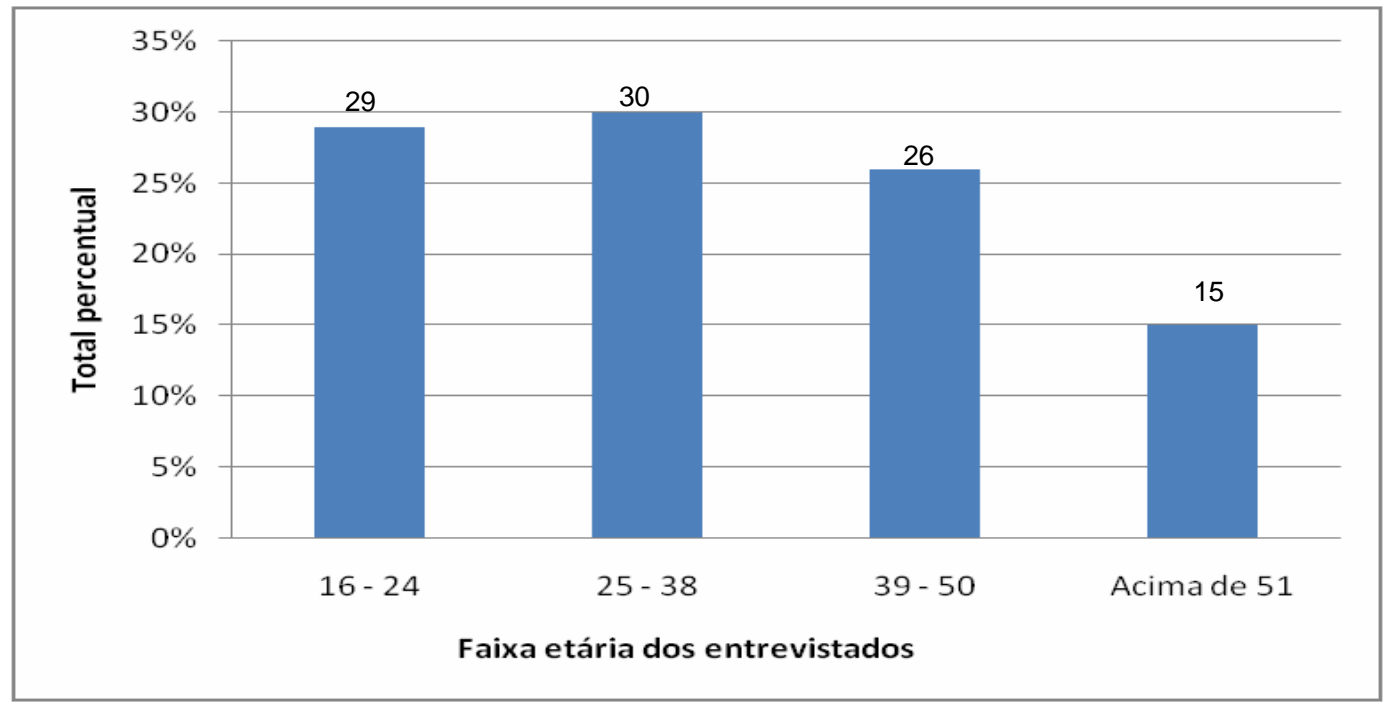

FIGURA 2 - Percentual da distribuição etária dos trabalhadores da cidade de Manaus no mês de maio de 2016. FONTE: Elaboração própria.

No que diz respeito ao vínculo empregatício, $81 \%$ estão trabalhando no momento como "empregado"; $5 \%$, como "empregador"; $11 \%$, como profissional liberal e o restante, como bolsista em alguma instituição.

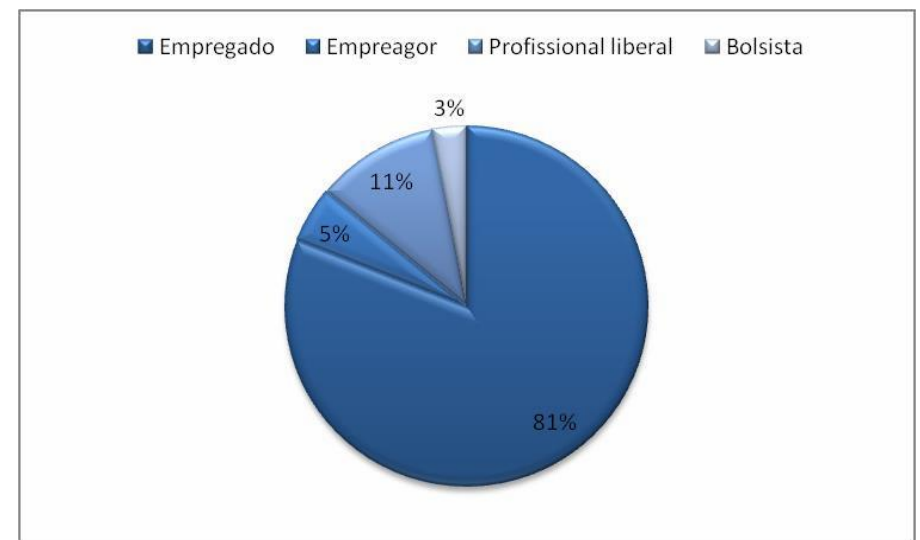

FIGURA 3 - Percentual por vínculo empregatício dos trabalhadores na cidade de Manaus no mês de maio de 2016 . FONTE: Elaboração própria.

A figura abaixo mostra que $55 \%$ dos trabalhadores são solteiros; $39 \%$, casados e $6 \%$, divorciados, o que geralmente está ligado ao número de dependentes financeiros, tendo em vista que, uma pessoa casada tende a constituir família, diferentemente de um cidadão solteiro. 


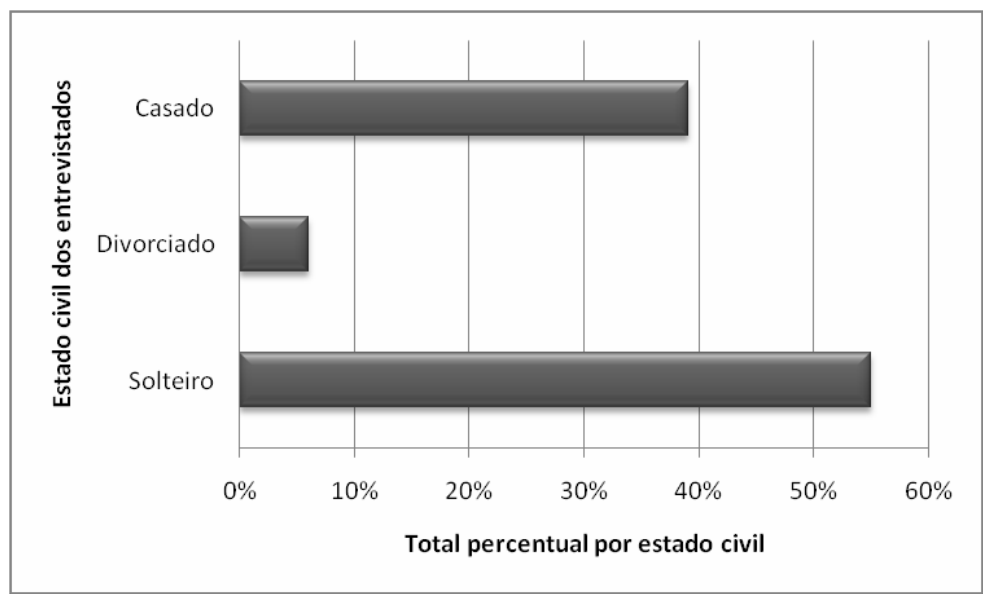

FIGURA 4 - Percentual por estado civil dos trabalhadores da cidade de Manaus no mês de maio de 2016. FONTE: Elaboração própria.

$\mathrm{Na}$ figura 5, é possível verificar que mais da metade dos entrevistados, exatamente $55 \%$, não apresentam dependentes financeiros e a sua renda é utilizada apenas consigo, sem precisar sustentar outro indivíduo.

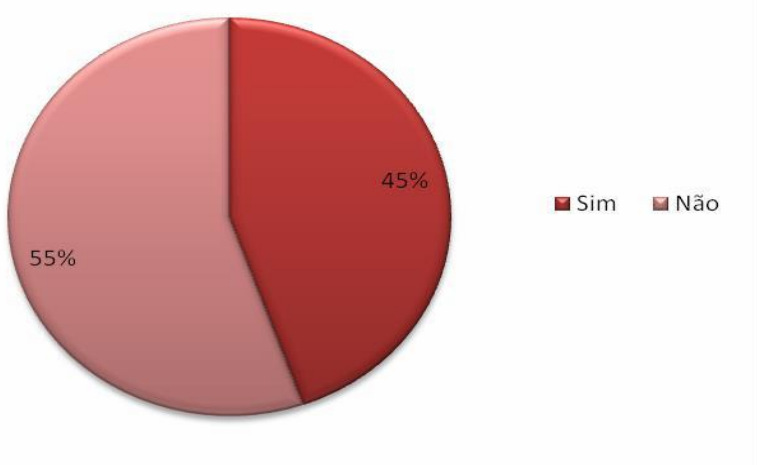

FIGURA 5 - Percentual dos trabalhadores de Manaus no mês de maio de 2016 que possuem dependentes financeiros. FONTE: Elaboração própria.

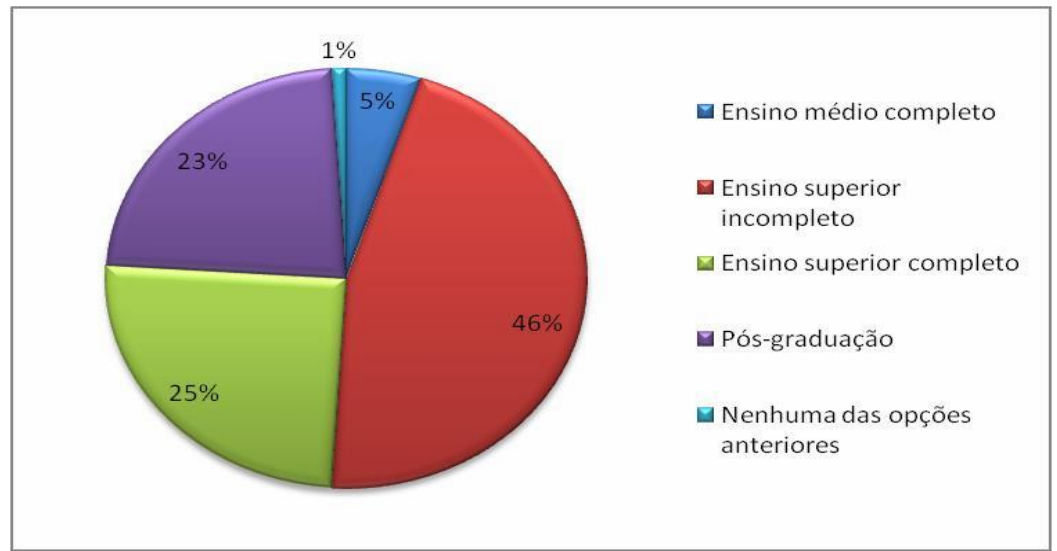

FIGURA 6 - Percentual total em relação ao nível de escolaridade dos trabalhadores na cidade de Manaus no mês de maio de 2016. FONTE: Elaboração própria.

A classificação do grau de escolaridade utilizada na pesquisa se deu a partir do Ensino Médio completo até a pós-graduação e foi observado um maior número de respostas para o grupo de respondentes que possuem o Ensino Superior incompleto, abarcando $46 \%$ do total daqueles que responderam ao questionário, como pode ser observado na figura 6.

Por intermédio da correlação entre as variáveis nível de escolaridade e os indivíduos que buscam por informações sobre educação financeira, foi possível constatar que $70 \%$ dos pós-graduados, os quais possuem um maior grau de escolaridade, são os que mais procuram informações sobre finanças pessoais e 
também são aqueles que reservam a maior parte da renda para investimentos. Com relação ao total dos indivíduos que possuem o ensino médio completo, $5 \%$ responderam que não sabiam que existem informações sobre este assunto e que também não possuem nenhum tipo de reserva financeira, ou seja, nenhum dinheiro guardado, o que pode ser explicado pelo fato de ainda não trabalharem.

\subsection{Dados da gestão das finanças pessoais}

A segunda parte do questionário estruturado foi usada para mensurar dados referentes à renda, investimento e conhecimento sobre finanças pessoais. Diante disso, constatou-se que $23 \%$ dos entrevistados possuem as rendas pessoais entre $R \$ 0,00$ a $R \$ 1.000,00$. Já aqueles que recebem um salário entre $R \$ 3.001,00$ a $R \$ 5.000,00$ também correspondem a $23 \%$ do total dos entrevistados, o qual pode ser observado na figura 7. O nível de renda dos entrevistados na Bahia por Santos e Silva (2014) é menor do que os respondentes em Manaus, haja vista que a renda dos $76,15 \%$ dos entrevistados na Bahia possuem renda entre 0,00 e $\mathrm{R} \$ 2.034,00$ e, em Manaus, $77 \%$ dos entrevistados possuem renda entre $\mathrm{R} \$ 1001,00$ a $\mathrm{R} \$ 5.001,00$. Também, observa que a renda dos respondentes em Manaus também é maior do que a renda dos entrevistados em Sergipe, haja vista que $58,46 \%$ dos entrevistados sergipanos possuem uma renda entre $\mathrm{R} \$ 676,00$ e $\mathrm{R} \$ 2.034,00$ e, em Manaus, $54 \%$ dos respondentes detêm renda no intervalo entre $R \$ 1.001,00$ e $R \$ 5.000,00$.

Correlacionando o nível de renda pessoal com as formas de controle sobre os gastos mensais, inferiu-se que, quanto maior a renda, mais o entrevistado procura ter um controle sobre seu consumo. Do total daqueles que possuem renda entre $R \$ 0,00$ a $R \$ 1.000,00$, aproximadamente, $40 \%$ não realizam controle, ou seja, não acompanham suas movimentações mensais sobre aquilo que gastam. Já todos que possuem renda superior a $\mathrm{R} \$ 5.000,00$ realizam controle sobre seus gastos mensais.

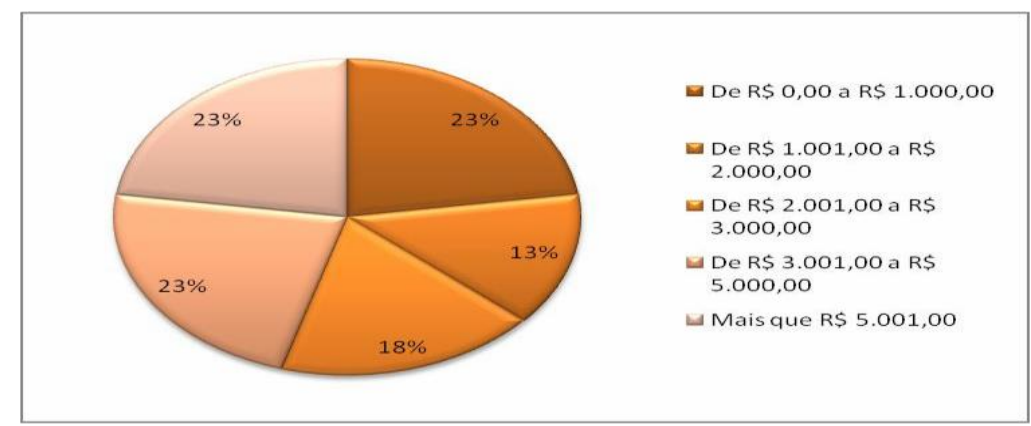

FIGURA 7 - Percentual de renda dos trabalhadores da cidade de Manaus no mês de maio de 2016.

FONTE: Elaboração própria.

A figura 8 ilustra que, dentre os entrevistados, $62 \%$ realizam algum tipo de investimento e o restante alega não investir por falta de planejamento financeiro e também pelo fato de as despesas do cotidiano serem altas, o que acarreta a falta de poupança para ser canalizada para algum investimento financeiro. Alguns citaram o pagamento do cartão de crédito no mês seguinte como fator de não acúmulo de poupança, o que inviabilizou a realização de algum tipo de investimento financeiro.

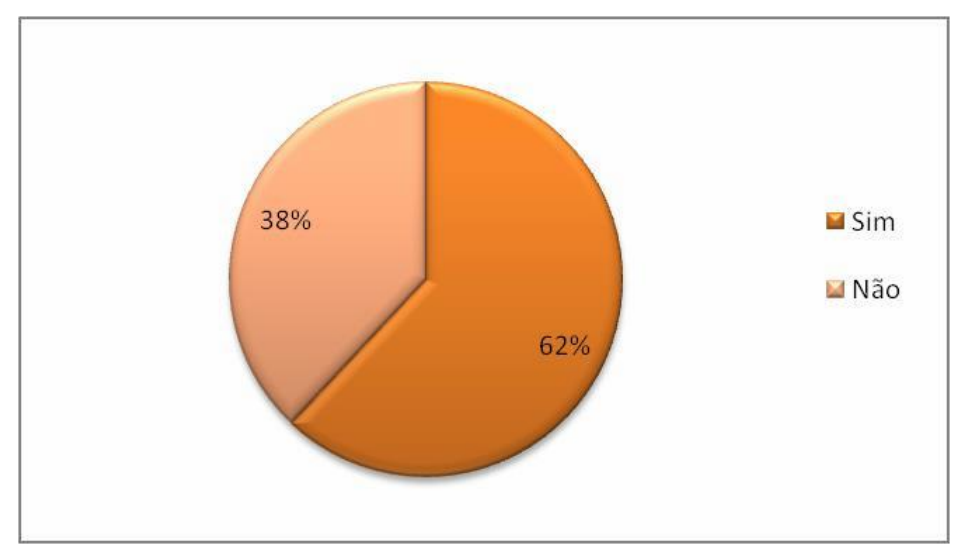

FIGURA 8 - Percentual dos trabalhadores na cidade de Manaus que reservam parte da renda para investimento no mês de maio de 2016.

FONTE: Elaboração própria. 
Ao serem perguntados se costumam procurar informações sobre finanças pessoais, $67 \%$ dos entrevistados responderam que sim, que procuram informações relacionadas a finanças pessoais, enquanto $29 \%$ dos entrevistados disseram que não costumam procurar informações e apenas $4 \%$ dos trabalhadores responderam que não sabiam que existiam informações sobre o assunto, como demonstrado na figura 9. Muitos dos que procuram informações sobre planejamento financeiro ou como minimizar as dívidas, não são capazes de manter uma disciplina para controlar as finanças pessoais, isto é, o conhecimento que é obtido por meio da internet, faculdade e revistas, não é colocado em prática, o que resulta no descontrole financeiro. Esse resultado não está de acordo com resultados encontrados por Santos e Silva (2014), constatando que o percentual dos respondents que não tiveram acesso ao conhecimento sobre educação financeira é maior do que os entrevistados que tiveram acesso a esse conhecimento na Bahia.

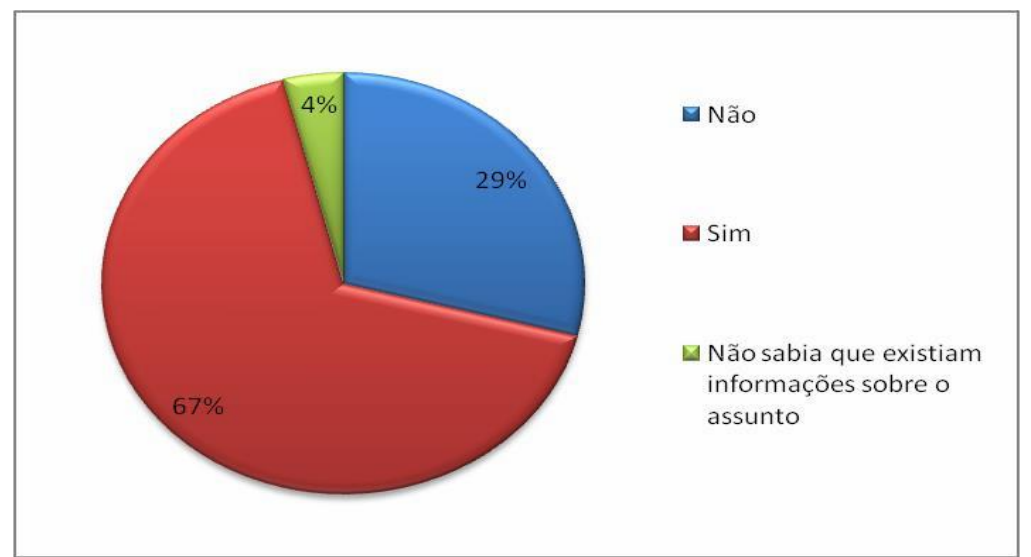

FIGURA 9 - Percentual dos trabalhadores que procuram buscar informações sobre finanças pessoais na cidade de Manaus no mês de maio de 2016.

FONTE: Elaboração própria.

Outra informação obtida foi sobre a frequência com que os trabalhadores entrevistados buscam informações, sendo que $6 \%$ responderam diariamente; $18 \%$, semanalmente; $8 \%$, mensalmente; $38 \%$ procuram só quando precisam ou quando desconhecem alguma nova determinação do mercado financeiro, e $30 \%$ nunca procuram ou procuram raramente, segundo informações da figura 10.

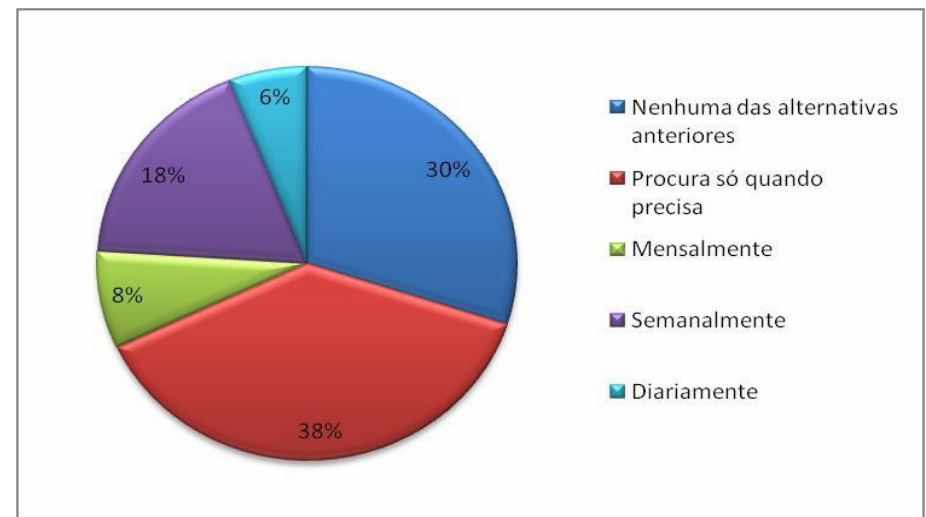

FIGURA 10 - Percentual da frequência dos trabalhadores da cidade de Manaus que buscam por informações sobre finanças pessoais para o mês de maio de 2016.

FONTE: Elaboração própria.

Já aqueles que conhecem algum órgão (governamental brasileiro) que disponibilize informações sobre educação financeira correspondem a $32 \%$ do total dos entrevistados (figura 11). Esse percentual é preocupante, pois existem muitos órgãos federais e estaduais que disponibilizam informações acerca do assunto, porém essas informações não são disseminadas entre a sociedade, o que gera preocupação para - Estado e seus governantes, pois uma população sem educação financeira tende a se tornar mais endividada (Enef, 2010).

Dentre os órgãos citados pelos entrevistados, estão Banco Central do Brasil, Sebrae e Tesouro Direto. Todos esses três órgãos disponibilizam programas para auxiliar os indivíduos que buscam diminuir o endividamento, ou melhorar, o planejamento financeiro. A figura 11 demonstra o percentual daqueles que possuem conhecimento da existência desses órgãos. 


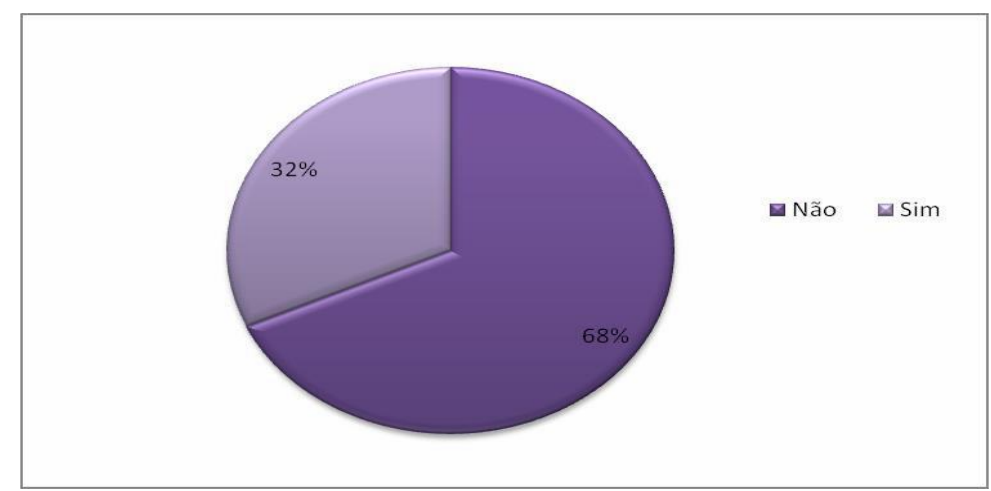

FIGURA 11 - Percentual de trabalhadores de Manaus que identificam algum órgão brasileiro que disponibilize informações sobre educação financeira no mês de maio de 2016.

FONTE: Elaboração própria.

Sobre a gestão de finanças pessoais, também foi questionado se os trabalhadores já participaram de algum evento formal relacionado à educação financeira, sendo que $67 \%$ responderam que ainda não participaram, embora tenham demonstrado interesse, pois acreditam que o tema ajudaria a melhorar 0 planejamento financeiro, o que iria contribuir na diminuição das dívidas.

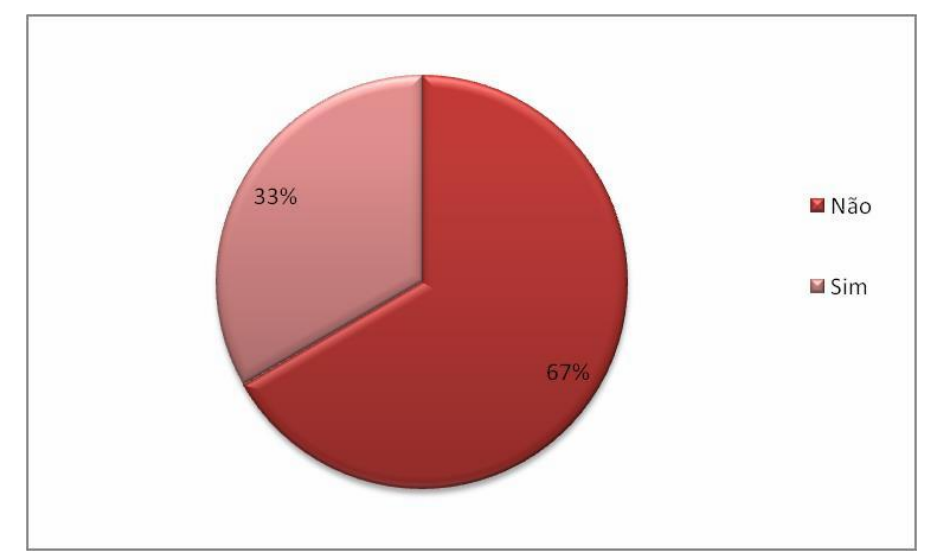

FIGURA 12 - Percentual de trabalhadores de Manaus que participaram de algum evento sobre educação financeira para o mês de maio de 2016.

FONTE: Elaboração própria.

$\mathrm{Na}$ figura abaixo, encontra-se o percentual daqueles trabalhadores entrevistados que gostariam de participar de algum evento relacionado à educação financeira ou planejamento orçamentário pessoal. Do total dos entrevistados, $85 \%$ responderam que possuem interesse em fazer parte de um evento desse tipo e reconhecem a importância para uma vida financeira saudável. Já 15\% dos respondentes disseram que não têm interesse em participar.

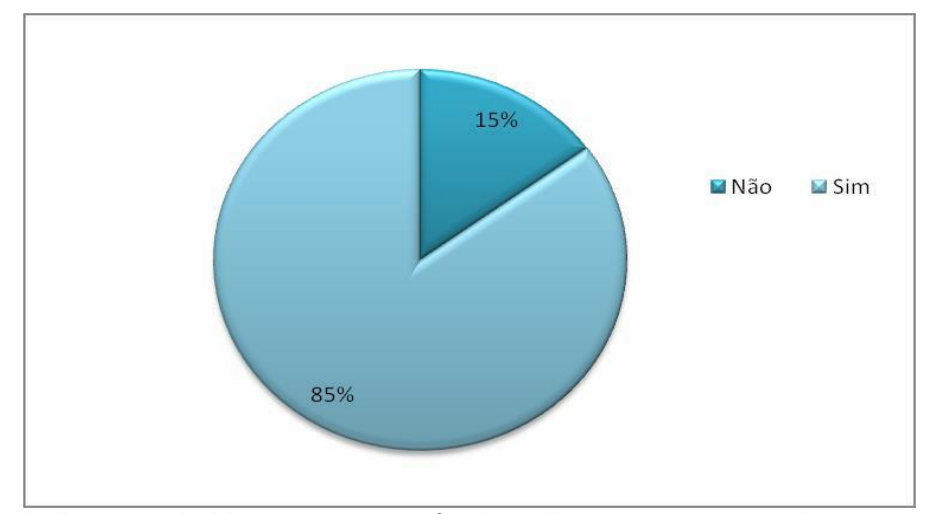

FIGURA 13 - Percentual de trabalhadores de Manaus para o mês de maio de 2016 que tem interesse em participar de algum evento relacionado à educação financeira.

FONTE: Elaboração própria. 
Para uma melhor compreensão a respeito de como os entrevistados ficaram sabendo da possibilidade de adquirir conhecimentos para administrar os recursos financeiros, foi elaborada a questão 14 , em que $30 \%$ responderam que aprenderam a importância de gerenciar o próprio dinheiro por meio de palestras, jornais, revistas, Internet e livros. Já $24 \%$ aprenderam na faculdade e com a experiência própria de situações vividas no dia a dia, como as situações que envolveram gastos que excederam a renda do próprio trabalhador, que acarretou em queda do consumo nos meses seguinte. Os outros $20 \%$ dos entrevistados aprenderam com os familiares. Esse percentual de 30\% para a cidade de Manaus é mais elevado do que os resultados encontrados por Piccini e Pinzetta (2014), que constataram, na cidade de Chapecó/SC, que apenas $5 \%$ do total possuem informação para gerir melhor os recursos e, assim, investir.

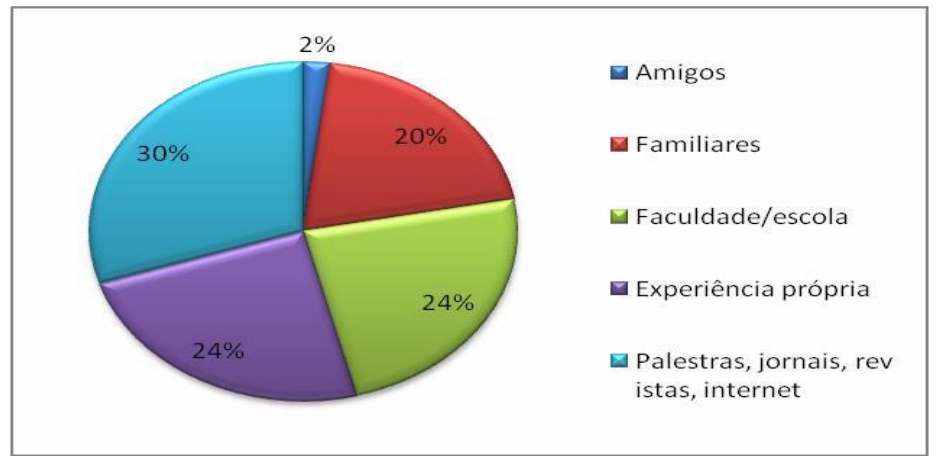

FIGURA 14 - Percentual de trabalhadores na cidade de Manaus para o mês de maio de 2016 que souberam como é possível adquirir conhecimentos para gerir o dinheiro.

FONTE: Elaboração própria.

Conforme visto no referencial teórico, um dos aspectos mais importante para o controle dos gastos é a elaboração de um planejamento financeiro, que procurou identificar, dentro do tópico de gestão de finanças pessoais, a maneira pela qual os entrevistados gerenciavam seus recursos financeiros, como, por exemplo, o emprego de algum tipo de controle e meio utilizado para monitorar o que gastam durante o mês. As informações da figura 15 mostram que a maior parcela dos entrevistados, composta por $24 \%$, utilizam do mecanismo da planilha eletrônica, logo em seguida está o modo mais tradicional, conhecido como caderno de anotações mensais usados por $21 \%$ dos entrevistados. A pesquisa mostra também que $14 \%$ da amostra ainda não utilizam nenhuma forma de gerenciar os recursos financeiros e reconhecem a falta do hábito para obter um controle das suas finanças. Como consequência da ausência da administração dos gastos, surge o endividamento e a falta de recursos para investimentos futuros.

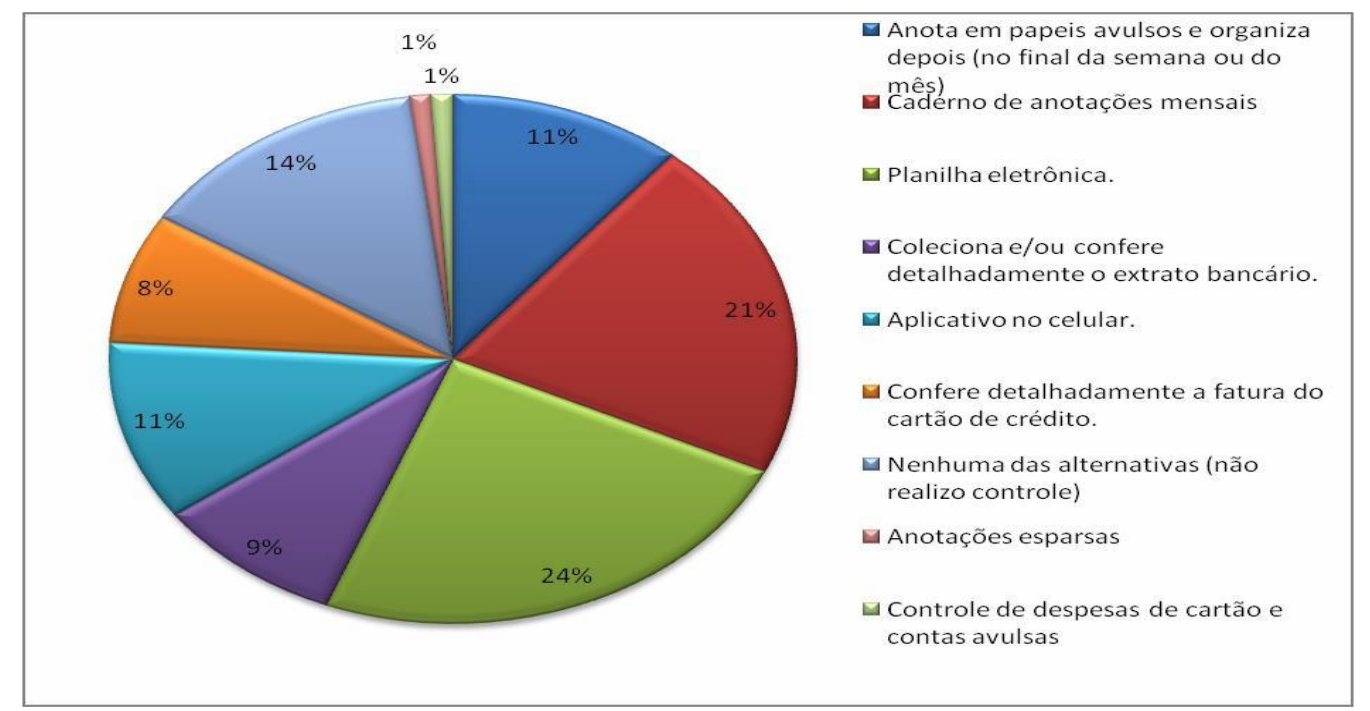

FIGURA 15 - Percentual dos trabalhadores de Manaus que utilizam meios para controlar os gastos para o mês de maio de 2016 . FONTE: Elaboração própria.

Conforme resultado da pesquisa de campo mostrado na figura 19, apenas 6 dos 66 entrevistados possuem bastante entendimento sobre finanças pessoais e administração financeira, o que acarreta melhor controle sobre o total dos gastos mensais. Logo em seguida, do total de entrevistados, $36 \%$ representam aqueles que dizem possuir um conhecimento seguro, isto é, conhecem grande parte das informações que precisariam saber sobre educação financeira, mas no contexto em que apareça nova oportunidade irão 
aprender ainda mais sobre gestão de finanças pessoais. Aqueles que responderam "nada seguro" gostariam de possuir um entendimento muito melhor sobre educação financeira, correspondendo a $11 \%$ dos trabalhadores entrevistados. A maioria dos respondentes, que correspondem a $44 \%$ do total dos entrevistados, acreditam possuir um conhecimento não muito seguro.

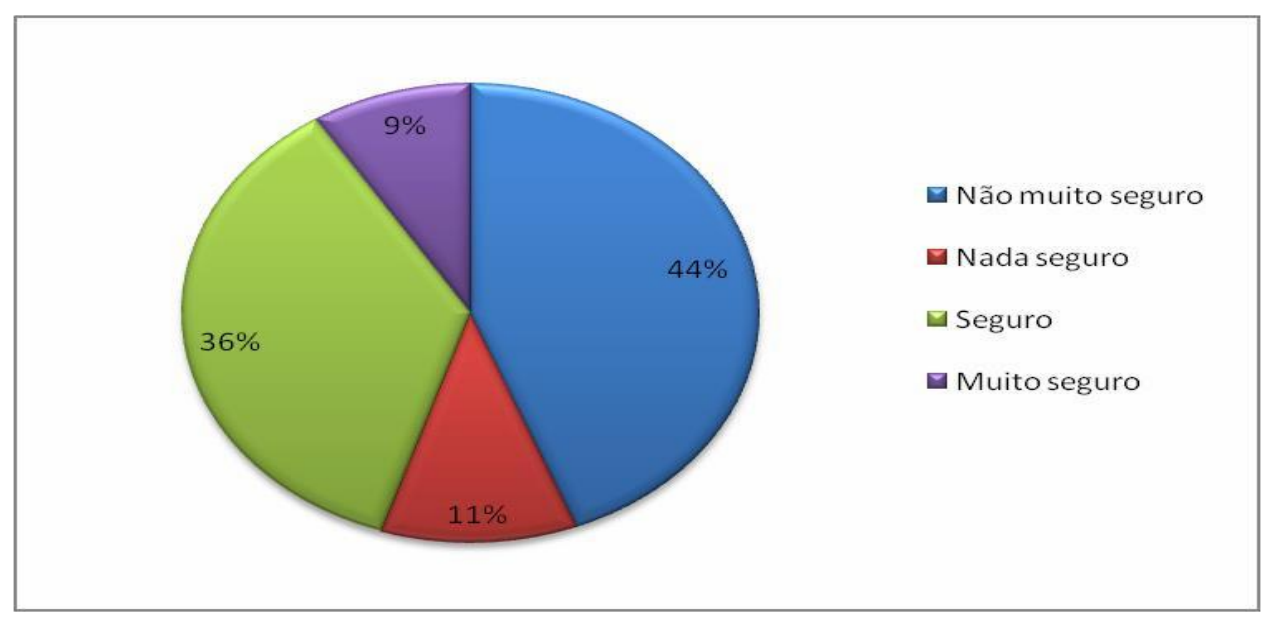

FIGURA 16 - Percentual de desempenho que os trabalhadores de Manaus possuem em relação aos conhecimentos financeiros para o mês de maio de 2016.

FONTE: Elaboração própria.

\subsection{Perfil das compras, despesas e pagamentos}

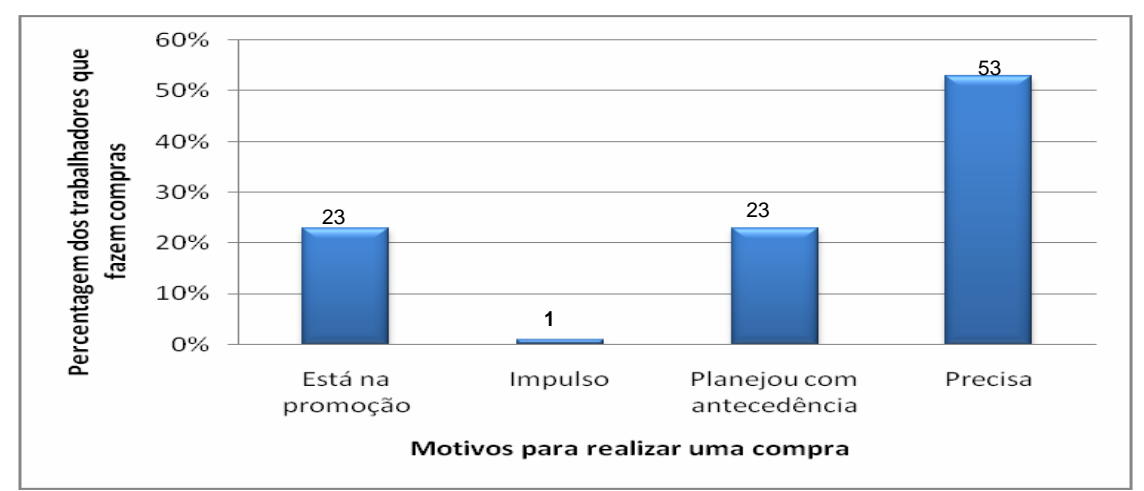

FIGURA 17 - Percentagem dos motivos que levam os trabalhadores da cidade de Manaus a realizar uma compra no mês de maio de 2016.

FONTE: Elaboração própria.

Para esta etapa da pesquisa, levou-se em consideração a maneira pela qual o entrevistado realiza pagamentos das despesas mensais, quais os objetivos principais ao se realizar uma compra e a situação financeira atual do mesmo. Ao analisar o que leva os respondentes a realizarem uma compra, 35 trabalhadores (53\%) responderam que precisam daquele bem no ato da compra. Com relação aos demais, $23 \%$ responderam que compram, pois está na promoção, mesmo sendo algum produto desnecessário no momento, mas que, no futuro, poderá ser útil. Outros $23 \%$ disseram que só adquirem algo se tiver sido planejado com antecedência, por exemplo, um vestido longo para ser usado em um casamento. Apenas uma pessoa respondeu que realiza compra por impulso.

Os resultados obtidos pela questão de número 17 mostram que $63 \%$ dos respondentes pagam à vista e de forma parcelada simultaneamente, utilizando-se do cartão de crédito. Isso ocorre pelo fato de este cartão proporcionar a aquisição de bens que não podem ser pagos totalmente à vista, fazendo com que algumas compras sejam efetuadas por meio dessas duas formas de pagamento. A segunda forma mais comum de pagamento é a totalmente à vista, representada por $23 \%$ dos entrevistados, em sua maioria jovens de 16 a 24 anos. Aqueles que utilizam apenas cartão de crédito representam uma minoria de $14 \%$, o que pode ser prejudicial para o planejamento financeiro, pois, de acordo com uma pesquisa feita pelo SPC Brasil, os principais problemas da utilização única do cartão de crédito são o descontrole dos usuários, que acarreta endividamento para muitos, além de incentivar gastos impulsivos e desnecessários (SPC, 2016). Se forem comparados os resultados deste estudo com os do trabalho de Santos e Silva (2014), nota-se que o percentual de pessoas que usam cartão de crédito é menor em Manaus (14\%) do que em Sergipe $(15,08 \%)$. 
Prosseguindo a análise, com relação ao pagamento das faturas do cartão de crédito, de acordo com a figura, 19,67\% paga na data de vencimento, percentual menor do que o encontrado no trabalho de Araujo e Calife (2014), o que representa uma atitude positiva para a saúde financeira, pois o pagamento após a data acumula juros e, dessa forma, aumenta as chances de endividamento do indivíduo. Já $28 \%$ dos entrevistados realizam o pagamento antes da data de vencimento, $2 \%$ fazem o pagamento frequentemente atrasado e $3 \%$ pagam a fatura sempre com atraso. Apesar de ser uma minoria, pelo resultado da pesquisa, ainda existem aqueles que possuem o hábito de quitar os gastos com atraso, elevando as chances de entrar no ciclo do endividamento. Esses resultados estão em linha com os resultados encontrados na Bahia por meio do estudo de Santos e Silva (2014), haja vista que a maioria dos respondents pagam tanto em Manaus $(95 \%)$ quanto na Bahia $(73,08 \%)$ em dia as contas, porém, em Manaus, o percentual é maior, logo o percentual daqueles que pagam as contas em Manaus $(5 \%)$ se comparado com a Bahia $(22,31 \%)$ é menor. Tanto os resultados do estudo de Araujo e Calife (2014), em que a maioria dos respondentes (65\%) realizam o pagamento à vista ou em parcela única.

Constatou-se que, dos entrevistados que utilizam o cartão de crédito ao realizar uma compra ou obter um serviço, $75 \%$ conseguem identificar os juros na transação comercial, ou seja, possuem conhecimento dos valores e riscos caso não cumpram com o devido pagamento. Os outros $25 \%$ não sabem exatamente o valor das tarifas que são cobradas e não analisam as taxas de juros quando finalizam uma compra, uma atitude negativa, dado que as taxas de juros do cartão de crédito estão elevadíssimas e, dessa forma, o consumidor pode prejudicar o orçamento financeiro pessoal e ter dificuldades para arcar com as dívidas.

Avaliou-se, também, se os entrevistados, em algum contexto, já tiveram a necessidade de renegociar alguma dívida ou obrigação, o resultado obtido mostrou que $50 \%$ deles precisaram e os demais não. Também foi questionado se os trabalhadores possuem prestações financeiras atrasadas, atualmente, e foi constatado que vinte entrevistados possuem obrigações com mais de três meses de atraso. Dentre as dívidas atrasadas, as mais citadas foram: prestação de carro, condomínio, IPTU, TV por assinatura e Internet. Imposto de renda e peças de vestuário também foram citados. A maioria dos que possuem prestações com mais de três meses de atraso é composta por $70 \%$ de mulheres, que possuem entre $30 \mathrm{e}$ 58 anos. Os resultados desse estudo mostram que o percentual de pessoas que detêm renda comprometida é menor em Manaus (30\%) do que em Chapecó, cuja percentagem dos respondentes que possuem renda comprometida é de $67 \%$.

\section{CONSIDERAÇÕES FINAIS}

Com relação à análise feita, observou-se que a maior parte dos trabalhadores possui o Ensino Superior incompleto e estão trabalhando, no momento, como empregados. Correlacionando a variável grau de escolaridade com a inadimplência no momento atual, não é possível, na pesquisa em questão, dizer que um trabalhador que possui pós-graduação é menos endividado do que aquele que possui o Ensino Superior, pois foi verificado que uma parte dos trabalhadores pós-graduados estava inadimplente e que já precisou renegociar alguma prestação/obrigação. Já com relação ao interesse e pesquisa por assuntos relacionados à educação financeira, os com maior nível de escolaridade (pós-graduados) são os que mais procuram assuntos relacionados ao tema e tentam aplicá-los na prática.

Outro fator relevante foi o nível de renda pessoal e as formas de controle sobre os gastos mensais, no qual foi demonstrado que todos os trabalhadores com renda superior a $R \$ 5.000,00$ realizam controle sobre seus gastos mensais, já uma parcela daqueles com renda inferior, não acompanham as movimentações mensais das despesas e receitas. Diante do resultado da pesquisa, também foi observado que muitos trabalhadores da cidade de Manaus não realizam qualquer tipo de investimento, e um dos principais motivos seriam as altas despesas do cotidiano, o que acarreta a falta de recursos financeiros para algum tipo de aplicação financeira.

A análise do efeito entre educação financeira e endividamento sobre os trabalhadores da cidade de Manaus aponta que todos aqueles que estão inadimplentes no momento atual foram os que disseram possuir um conhecimento "não muito seguro" e "nada seguro", certificando-se que gostariam de possuir um entendimento muito melhor sobre educação financeira, de modo a contribuir para um bom planejamento orçamentário pessoal e otimizando as decisões de consumo, bem como sanar as dívidas existentes.

\section{REFERÊNCIAS BIBLIOGRÁFICAS}

ARAÚJO, F. C. e CALIFE, F. E. A história não contada da Educação Financeira no Brasil., 2014. Disponível em <http://www.boavistaservicos.com.br/wpcontent/uploads/2014/08/A-hist\%C3\%B3ria-n\%C3\%A3o-contadadaeduca\%C3\%A7\%C3\%A3o-financeira-no-Brasil.pdf> Acesso em: 16 de ago. 2015. 
BANCO CENTRAL DO BRASIL. BACEN. O Programa de Educação Financeira do Banco Central. 2013. Disponível em <http://www.bacen.gov.br/?BCEDFIN>. Acesso em: 09/05/2016.

BOA VISTA SERVIÇOS - SPC. Inadimplência do consumidor cresce 3,2\% nos últimos 12 meses. 2016. Disponível em: <http://www.boavistaservicos.com.br/noticias/indicadores- economicos/registro-deinadimplencia/inadimplencia-do-consumidor-cresce-32-nos-ultimos- 12-meses/> Acesso em: 23 de junho. 2016.

BORGES, Paulo Roberto Santana. Educação financeira e sua influência no comportamento do consumidor no mercado de bens e serviços. In: Encontro de produção científica e tecnológica da fecilcam, 5.,2010, Campos Mourão. Anais eletrônicos...Campos Mourão: Fecilcam, 2010. Disponível em http://www.fecilcam.br/nupem/anaisv epct/PDF/ciencias sociais/04 BORGES.pdf. Acesso em: 20 out 2013.

BRASIL. Comitê Nacional de Educação Financeira. Plano Diretor da Estratégia Nacional de Educação Financeira. Brasília, 2009. Disponível em: http://www.vidaedinheiro.gov.br/docs/PlanoDiretorENEF.pdf. Acesso em: 15 ago. 2016.

CABRAL, B, B. Educação Financeira: O primeiro passo para o consumo consciente. Acadêmico mundo Multidisciplinar. Bahia, v. 1, n. 2, out. 2013. Disponível em: http://www.academicomundo.com.br/revista_2.html. Acesso em 11 de Maio de 2016.

CENTRALIZAÇÃO DOS SERVIÇOS BANCÁRIOS S/A - SERASA. Guia SERASA de orientação dos cidadãos. Disponível em: http://www.serasaexperian.com.br/educacaofinanceira/v2/index.htm. Acesso em: 30/06/2015.

COMISSÃO DE VALORES IMOBILIÁRIOS. CVM. Planejamento Estratégico Construindo a CVM de 2023.2013. Disponível em: http://www.cvm.gov.br/export/sites/cvm/menu/acesso_informacao/planos/estrategico/Planeja mento_estrategico_CVM_2013_2023.pdf>. Acesso em 20 de junho 2016.

FERREIRA, Vera Rita. Porque o endividamento das pessoas tem crescido? 2007. Disponível em: www.clubedosendividados.com.br. Acesso em: 10/07/2015.

GALLERY, N.; GALLERY, G.; BROWN, K.; FURNEAUX, C.; PALM, C. Financial literacy and pension investment decisions. Financial Accountability \& Management, EUA, v. 27, n. 3, p. 286-307, 2011.

GARMAN, E, T.; KIM,J.; KRATZER,C,Y.; BRUNSON,B,H.,JOO,S,H. Workplace Financial Education Improves Personal Financial Improves. Financial Counseling and Planning, n. 1, v. 10, sept, 2010.

GIL, Antônio Carlos. Como elaborar projeto de pesquisa. 4ª Ed. São Paulo: Atlas, 2002. 176 p.

Günther, H. (2003). Como Elaborar um Questionário (Série: Planejamento de Pesquisa nas Ciências Sociais, No 01). UNB, Laboratório de Psicologia Ambiental, Brasília, $2003<$ www.psiambiental.net/pdf/01Questionario.pdf>.

HOUAISS, A. Dicionário Houaiss da Língua Portuguesa. Rio de Janeiro: Objetiva, 2001.

JACOB, K., SHARYL, H., MALCOLM, B. Tools for survival: An analysis of financial literacy programs folowerincome families. Chicago: WoodstokInstitute, Jan/2000.

KATONA, G. Psychological Economics. New York: Elsevier, 1975, p. 438.

MALLMANN, Estela Isabel et al. Finanças Pessoais: Análise dos gastos e da propensão ao endividamento em estudantes de Administração. In: XII SEMEAD, 2009, São Paulo. XII SEMEAD: Empreendedorismo e Inovação, 2009.

OECD - ORGANISATION FOR ECONOMIC CO-OPERATION AND DEVELOPMENT. Project on Financial Education. 2009.

MANDELL, L.;KLEIN,L,S. The impact of Financial Literacy Education on Subsequent Financial Behavior. Journal of Financial Counseling and Planning, n. 1, v. 20, oct, 2009.

PICCINI, R, A, B.; PINZETTA, G. Planejamento Financeiro Pessoal e Familiar. Unoesc \& Ciência - ACSA, Joaçaba, v. 5, n. 1, p. 95-102, jan./jun. 2014.

RAMPAZZO, Lino. Metodologia Científica para alunos dos cursos de graduação e pós-graduação. 3. ed. São Paulo: Loyola, 2005.

SANTOS, A, C.; SILVA, M. Importância do Planejamento Financeiro no Processo de Controle do Endividamento Familiar: Um Estudo de Caso nas Regiões Metropolitanas da Bahia e Sergipe. Revista Formadores: Vivências e Estudos, Cachoeira-BA, v. 7, n. 1, p. 5-17, jun, 2014.

TEIXEIRA, A. F.; SILVA, R. A. Créditos de difícil recebimento: crédito, cobrança, inadimplência e os seus tratamentos contábeis. 1. ed. Franca: Facef, 2001. p. 19-20.

TOLOTTI, M. Dívidas: conheça os tipos de endividados e saiba evitar essa situação. Infomoney. 18 de outubro de 2010. Disponível em: <http://www.infomoney.com.br/minhas-financas/planeje-suas-financas/noticia/825305/dividasconheca-tipos-endividados-saiba-evitar-essa-situacao> Acessado em 12/11/2015.

. As armadilhas do consumo: acabe com o endividamento. Rio de Janeiro: Elsevier, 2007. 
